\title{
Stereotactic body radiation therapy versus surgical resection for stage I non-small cell lung cancer
}

\author{
Traves D. Crabtree, MD, ${ }^{a}$ Chadrick E. Denlinger, MD, ${ }^{a}$ Bryan F. Meyers, MD, ${ }^{a}$ Issam El Naqa, PhD, ${ }^{b}$ \\ Jennifer Zoole, BSN, ${ }^{\mathrm{a}}$ A. Sasha Krupnick, MD, ${ }^{\mathrm{a}}$ Daniel Kreisel, MD, ${ }^{\mathrm{a}} \mathrm{G}$. Alexander Patterson, MD, ${ }^{\mathrm{a}}$ and \\ Jeffrey D. Bradley, $\mathrm{MD}^{\mathrm{b}}$
}

\begin{abstract}
Objectives: Stereotactic body radiation therapy has been proposed as an alternative local treatment option for high-risk patients with early-stage lung cancer. A direct comparison of outcomes between stereotactic body radiation therapy and surgical resection has not been reported. This study compares short-term outcomes between stereotactic body radiation therapy and surgical treatment of non-small cell lung cancer.
\end{abstract}

\begin{abstract}
Methods: We compared all patients treated with surgery (January 2000-December 2006) or stereotactic body radiation therapy (February 2004-May 2007) with clinical stage IA/B non-small cell lung cancer staged by computed tomography and positron emission tomography. Comorbidity scores were recorded prospectively using the Adult Co-Morbidity Evaluation scoring system. Charts were reviewed to determine local tumor recurrence, disease-specific survival, and overall survival. A propensity score matching analysis was used to adjust estimated treatment hazard ratios for confounding effects of patient age, comorbidity index, and clinical stage.
\end{abstract}

Results: A total of 462 patients underwent surgery and 76 received stereotactic body radiation therapy. Overall, surgical patients were younger $(P<.001)$, had lower comorbidity scores $(P<.001)$, and better pulmonary function (forced expiratory volume in 1 second and carbon monoxide diffusion in the lung) $(P<.001)$. Among the surgical and stereotactic body radiation therapy groups, 62.6\% (291/462) and 78.9\% (60/76) were in clinical stage IA, respectively. Final pathology upstaged 35\% (161/462) of the surgery patients. In an unmatched comparison, overall 5-year survival was 55\% with surgery, and the 3-year survival was $32 \%$ with radiation therapy. Among patients with clinical stage IA disease, 3 -year local tumor control was $89 \%$ with radiation therapy and $96 \%$ with surgery $(P=.04)$. There was no difference in local tumor control in stage IB disease $(P=.89)$. No disease-specific survival differences were found in patients with 1A $(P=.33)$ or IB disease $(P=.69)$. Propensity analysis matched 57 high-risk surgical patients to 57 patients undergoing stereotactic body radiation therapy. In the matched comparison of this subgroup, there was no difference in freedom from local recurrence $(88 \%$ vs $90 \%$ ), disease-free survival ( $77 \%$ vs $86 \%$ ), and overall survival (54\% vs $38 \%)$ at 3 years.

Conclusions: In an unmatched comparison of clinical stage IA disease, surgical patients were healthier and had better local tumor control compared with those receiving stereotactic body radiation therapy. Propensity analysis in clinical stage IA/B non-small cell lung cancer revealed similar rates of local recurrence and disease-specific survival in patients treated with surgery compared with stereotactic body radiation therapy. (J Thorac Cardiovasc Surg 2010;140:377-86)

\footnotetext{
Optimal management of very high-risk patients with earlystage lung cancer remains a difficult challenge for the treating physician. Poor pulmonary function and cardiac-related morbidity can limit the available treatment options. Although it is speculated that mortality in these high-risk patients commonly results from their comorbid conditions,

From the Departments of Thoracic Surgery ${ }^{\mathrm{a}}$ and Radiation Oncology, ${ }^{\mathrm{b}}$ Washington University School of Medicine, St Louis, Mo.

Disclosures: None.

Presented in abstract form at the Eighty-ninth Annual Meeting of The American Association for Thoracic Surgery, Boston, Massachusetts, May 9-13, 2009.

Received for publication May 10, 2009; revisions received Sept 20, 2009; accepted for publication Dec 1, 2009; available ahead of print April 19, 2010.

Address for reprints: Traves D. Crabtree, MD, 3108 Queeny Tower, One Barnes Jewish Hospital Plaza, St Louis, MO 63110 (E-mail: crabtreet@wustl.edu). $0022-5223 / \$ 36.00$

Copyright $(C 2010$ by The American Association for Thoracic Surgery doi:10.1016/j.jtcvs.2009.12.054
}

population-based studies have shown that when left untreated, patients with early-stage lung cancer die of their cancer, rather than of competing causes of death. ${ }^{1,2}$

Although surgical resection remains the standard of care for early-stage lung cancer, new technology in radiation therapy provides for more concentrated, focused therapy that may improve efficacy and decrease toxicity compared with traditional external beam radiation. Stereotactic radiation therapy has been used for many years for the treatment of intracranial lesions not amenable to surgical resection. The application of this therapy has been extended to extracranial tumors and is often referred to as stereotactic body radiation therapy (SBRT). SBRT delivers high-dose radiation over 3 to 5 treatment fractions using multiple conformal coplanar and non-coplanar beams. This technique concentrates the prescribed radiation dose to the tumor more 


\section{Abbreviations and Acronyms}

$$
\begin{aligned}
& \text { ACE-27 }=\text { Adult Co-Morbidity Evaluation-27 } \\
& \text { CT }=\text { computed tomograph } \\
& \text { FEV }_{1}=\text { forced expiratory volume in } 1 \text { second } \\
& \text { NSCLC }=\text { non-small cell lung cancer } \\
& \text { PET }=\text { positron emission tomography } \\
& \text { PSM }=\text { propensity score matching } \\
& \text { SBRT }=\text { stereotactic body radiation therapy }
\end{aligned}
$$

precisely than conventional radiation therapy. Local tumor control rates with SBRT range between $85 \%$ and $95 \%$ at 3 to 5 years. ${ }^{3-7}$ SBRT also limits the acute complications frequently seen with external beam therapy. ${ }^{3-6}$ Severe acute toxicity from SBRT ranges from $2 \%$ to $8 \%$ with only 1 reported treatment-related death in several studies. ${ }^{5-7}$

Many prospective studies of SBRT in high-risk patients have been reported, with 2-year survival ranging from $47 \%$ to $77 \%{ }^{3,4,7,8}$ Five-year survival has been reported as $36.5 \%$ to $47 \%$ with longer follow-up. ${ }^{3-7}$ Examining the surgical experience in patients of varying risks, 5-year survival for pathologic stage IA and IB disease is $73 \%$ and $54 \%$, respectively. ${ }^{9}$ For clinical stage IA and IB disease, the 5-year survival is $50 \%$ and $40 \%$, respectively. ${ }^{9} \mathrm{Al}-$ though prospective clinical trials are underway, there are no direct comparisons of SBRT versus surgery in the management of early-stage lung cancer to date.

Our primary objective is to compare short-term outcomes between patients undergoing primary treatment with SBRT versus surgical resection for clinical stage I non-small cell lung cancer (NSCLC) (T1 or T2 N0 M0) at our institution. Propensity matched analysis enabled comparisons between high-risk patients in the surgical group and patients receiving SBRT to examine survival in this subgroup.

\section{METHODS}

All surgical patients with clinical stage I lung cancer treated between January 1, 2000, and December 31, 2006, and all patients between February 1, 2004, and May 5, 2007, with clinical stage I lung cancer undergoing treatment with SBRT were included and analyzed according to a protocol approved by our institutional review board. Not all patients receiving SBRT in this study had pathologic diagnoses, although referral for a computed tomography (CT)-guided biopsy was requested in all patients. The patients without a histologic diagnosis were considered to be too high of a risk for pneumothorax by our inteventional radiologists. A biopsy was refused by 3 patients. In addition, all tumors in the SBRT group were nodular lesions that were very suggestive of malignancy (ie, solid, spiculated) by CT or demonstrated growth on serial CT scans. Each of these patients underwent positron emission tomography-computed tomography (PET-CT) for staging. None had evidence of metastatic adenopathy and each of the lesions subjected to SBRT was considered malignant. The very high-risk patients undergoing SBRT did not routinely undergo staging mediastinoscopy or endobronchial ultrasonography. Clinical staging was done with CT and PET imaging in these patients. All CT scans and PET scans were reviewed in the surgical group to include only those patients with clinical stage I lung cancer. Comorbidity scores were recorded prospectively using the Adult Co-Morbidity Evaluation (ACE-27) scoring system. Charts were reviewed to determine local tumor recurrence, disease-specific survival, and overall survival. Propensity score matching (PSM) was performed on the basis of preoperative comorbidities and lung function. The ACE-27 form (Appendix A) was used to stratify pretreatment comorbidity in both groups. The comorbidity scores on all patients included in the trial were collected prospectively from the Oncology Data Services database managed by the Clinical Outcomes Research Office at Washington University. Exclusion criteria include patients with small cell lung cancer or other cancers that had metastasized to the lung, patients undergoing resection for benign disease, patients without preoperative staging chest CT and fluorodeoxyglucose PET scans, patients with tumors graded $\mathrm{T} 3$ or greater, patients with clinical N1 or N2 disease noted on preoperative imaging, and patients with concurrent malignancy within the year before treatment. Data on patient demographics, history and physical examination, evaluation by chest $\mathrm{CT}$, fluorodeoxyglucose PET scans, operative report, and final pathology reports (where available) were obtained from medical records.

In the surgical patients, the type of incision, type of resection (ie, lobar or sublobar), and extent of lymph node dissection were at the discretion of the treating surgeon. Patients undergoing SBRT were discussed at a multidisciplinary conference and were deemed to have inoperable disease by thoracic surgeons unless the patient simply refused surgical intervention. Current standard dosing delivers 54 Gy in 3 fractions over 8 to 14 days as currently recommended by the Radiation Therapy Oncology Group. The SBRT device used in this study is the Trilogy system produced by Varian Medical Systems, Inc (Palo Alto, Calif). This device does not generally require the placement of fiducial markers. Each tumor is localized by cone-beam CT on the Trilogy unit, axial, coronal, and sagittal alignment is matched to the treatment plan, and therapy is delivered. In a few of our patients, fiducial markers were placed to help clarify tumor position because of location near the mediastinum or diaphragm. A total of 10 to 12 non-coplanar beams deliver the prescribed radiation dose to the periphery of the planning target volume. The dose is typically prescribed to the $80 \%$ to $85 \%$ isodose line, meaning that the center of the tumor received a dose that is $15 \%$ to $20 \%$ higher than the prescription. Toxicity of SBRT was graded using the National Cancer Institutes Common Toxicity Criteria version 3.0.

Statistical analysis was performed using SPSS 11.0 for Windows (SPSS, Inc, Chicago, Ill) and Matlab (Mathworks, Inc, Natick, Mass). Descriptive statistics such as mean and median were presented for continuous variables whereas counts and proportions were presented for categorical data. Differences in mean were estimated by 2-tailed $t$ test, in median using the Wilcoxon rank sum, and in proportions using the $\chi^{2}$ test. Multivariate analysis of prognostic factors was performed using the Cox proportional hazards model. Treatment groups matching based on selected covariates was performed using PSM. In the PSM analysis, logistic regression was used to estimate the corresponding scores from the baseline patient covariates. To find matched patients from the 2 groups, we adopted a caliper matching approach. In this approach, both treatment groups are randomly sorted and then the datasets are matched using nearest neighbor distance in terms of the propensity score that is within an acceptable distance, called a "caliper." This approach has the ability to avoid bad matches (too large differences in propensity scores) compared with classic PSM methods.

\section{RESULTS}

A total of 462 patients with clinical stage I disease met inclusion criteria and underwent surgical resection during the defined study period whereas 76 underwent SBRT since the institution of this technology. All patients among each treatment group were clinically staged with CT and PET imaging. Median follow-up in the SBRT and surgical groups was 19 and 31 months, respectively. 

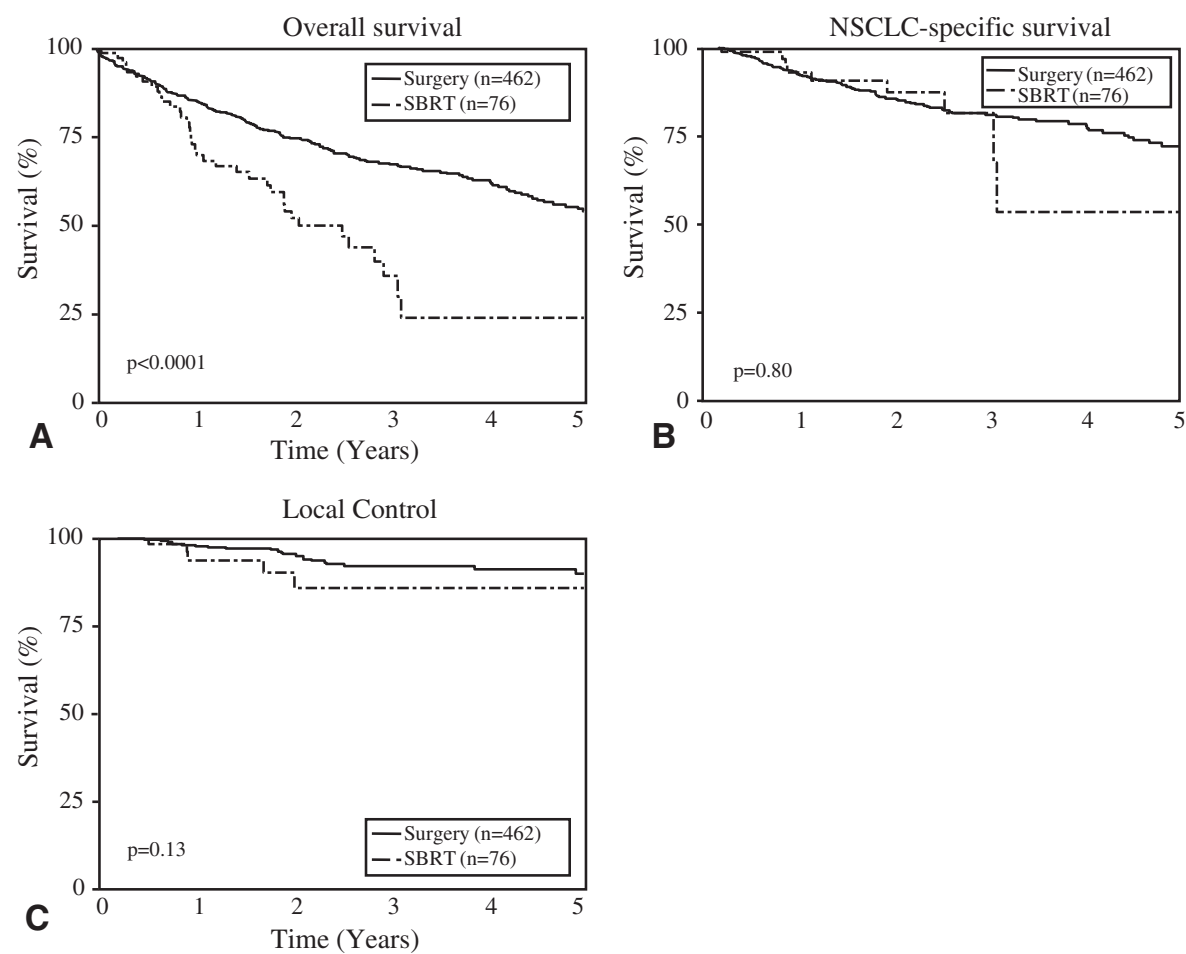

FIGURE 1. A, Overall survival in surgically treated patients versus patients receiving SBRT for clinical stage I lung cancer. B, Disease-specific survival in surgically treated patients and patients receiving SBRT for clinical stage I lung cancer. C, Local tumor control in surgically treated patients and patients receiving SBRT for clinical stage I lung cancer. SBRT, Stereotactic body radiation therapy; NSCLC, non-small cell lung cancer.

Among the SBRT patients, 61 (80\%) had biopsy-proven disease before treatment, but $15(20 \%)$ either refused biopsy $(n=3)$ or were unable to undergo a biopsy $(n=12)$. In each case the decisions to proceed with SBRT treatments in the absence of tissue diagnoses were made in the context of our multidisciplinary conference, which includes input from surgeons, oncologists, radiation oncologists, and radiologists. The average size of nodules lacking tissue diagnosis was $2.0 \mathrm{~cm}$ (median $1.8 \mathrm{~cm}$ ), and 6 of 15 had documented growth on serial CT scans. In addition, 14 of 15 patients lacking histologic diagnosis had PET scans showing hypermetabolic nodules with a mean maximum standardized uptake value of 6.3 (median 6.1). The remaining patient without a PET scan had a known brain metastasis with adenocarcinoma. In the SBRT group, there was no difference in local control $(P=.3)$, disease-free survival $(P=.5)$, and overall survival $(P=.4)$ for patients who had a pretreatment diagnosis versus those who did not.

The overall 5-year survival among patients with a diagnosis of clinical stage IA or IB NSCLC treated surgically in this series was $55 \%$. Owing to the lack of longer follow-up data to adequately estimate 5-year survivals for the SBRT group, 3-year overall and disease-specific survivals were determined for both the surgery and SBRT groups. The overall 3 -year survival for surgically treated patients was $68 \%$ compared with a 3-year survival of $32 \%$ among patients receiving SBRT (Figure 1, A). The cancer-specific survival at
3 years was similar in both groups $(82 \%)$ (Figure 1,B) Similarly, there was no significant difference in local control at 3 years in patients treated with surgery $(94 \%)$ versus SBRT $(89 \%)(P=.13)$ (Figure 1, $C)$.

In the unmatched comparison, patients with clinical stage IA disease demonstrated no significant difference between groups in disease-free survival (Figure 2, A). However, the 3 -year local tumor control was $89 \%$ with SBRT and $96 \%$ with surgery $(P=.04)$ in patients with clinical stage IA disease (Figure 2, $B$ ). There was no difference in either local tumor control $(91 \%$ vs $95 \%)$ or lung cancer-specific free survival ( $75 \%$ vs $67 \%)$ among patients with stage IB disease between patients treated surgically and those receiving SBRT, respectively (Figure 2, $C$ and $D$ ).

Inasmuch as surgery is considered the standard of care for patients with adequate lung function, and SBRT is reserved predominantly for patients considered to be medically inoperable owing to cardiac or pulmonary comorbidities, the 2 treatment groups were not equally matched. As shown in Table 1, surgically treated patients were younger $(P<.001)$, had lower comorbidity scores $(P<.001)$, and had better pulmonary function (forced expiratory volume in 1 second $\left[\mathrm{FEV}_{1}\right]$ and carbon monoxide diffusion in the lung) $(P<.001)$. Among the surgical and SBRT groups, $62.6 \%(291 / 462)$ and $75 \%(57 / 76)$ were in clinical stage IA, respectively. The remaining patients in each group were in clinical stage IB. Among patients treated with 

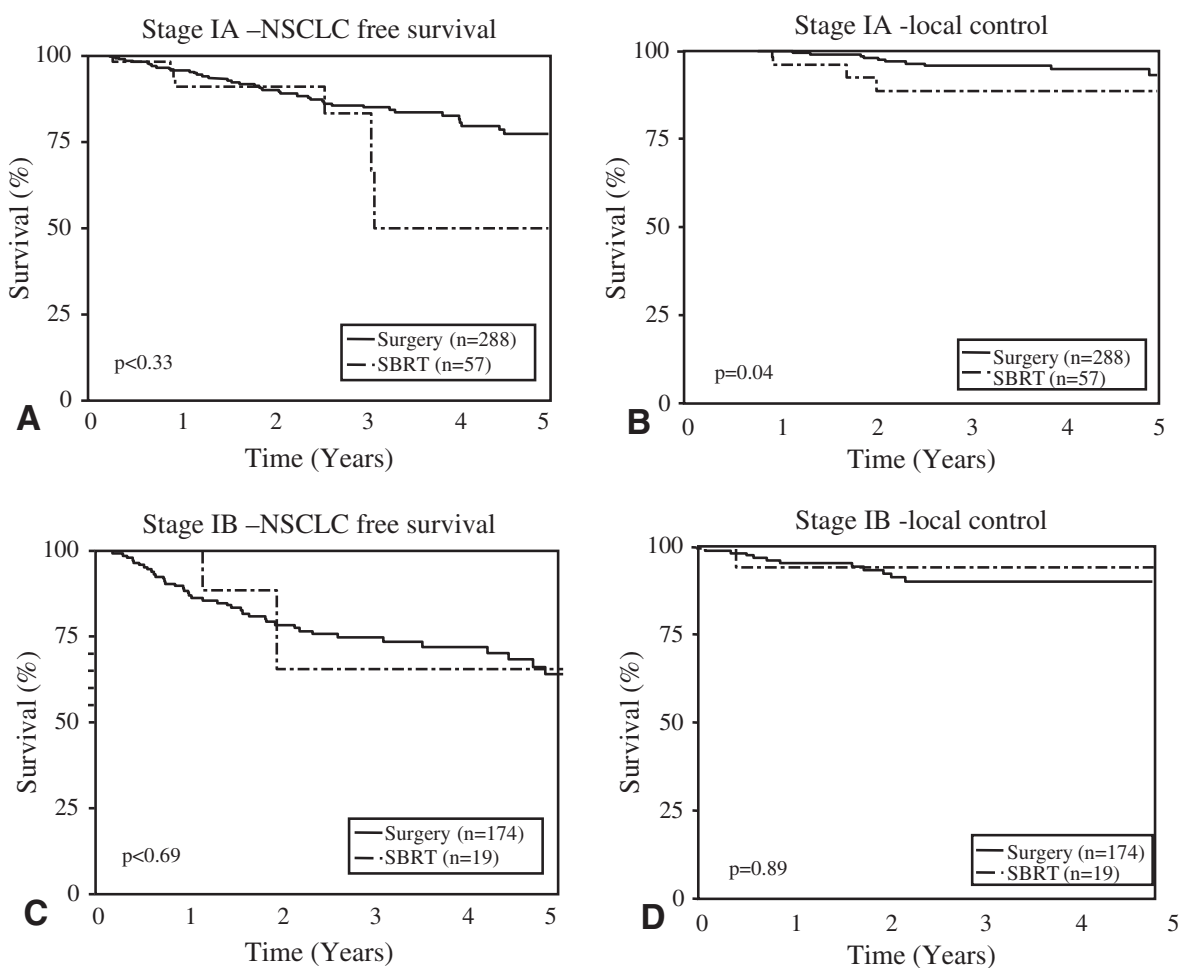

FIGURE 2. Disease-free survival and local tumor control in surgically treated patients versus patients receiving SBRT for clinical stage IA NSCLC (A and B). Disease-free and local tumor control in surgical treated patients versus patients receiving SBRT for clinical stage IB NSCLC (C and D). SBRT, Stereotactic body radiation therapy; NSCLC, non-small cell lung cancer.

surgery, the final pathology upstaged $35 \%$ of patients (161/ 462). Sixty-four $(13.8 \%)$ patients were found to have N1 disease with the final pathologic analysis and an additional $16(3.5 \%)$ patients were found to have pathologic N2 disease. In addition, 43,18 , and 19 patients were upstaged to pathologic T2, T3, and T4 tumors, respectively. In a single patient, M1 disease was diagnosed by the identification of synchronous tumor in a separate lobe at the time of surgery. Pathologic upstaging by initial clinical stage is displayed in Figure $3, A$ and $B$.

A multivariable Cox proportional hazards model was used to adjust estimated treatment hazard ratios for confounding effects of patient age, comorbidity index, and clinical stage. Table 2 outlines these results. In addition, because of the significant differences in patient comorbidities noted between patients treated surgically and patients who received SBRT, propensity matching was performed to identify 2 similar groups of patients within the surgical and SBRT treatment groups. These groups were matched with regard to age, clinical stage, and ACE-27 comorbidity score, which takes into account pulmonary function and cardiac risk factors. Caliper-based PSM analyses were performed to match surgical patients to the 76 patients who received SBRT. Table 3 demonstrates the results of each analysis based on different selections of the caliper parameter $(0.0005,0.001$, and 0.005$)$, starting with most constringent matches and reducing the distance different constraint afterward. The acuity of the SBRT group made it difficult to match surgical patients, thus the need for multiple analyses to provide the reader with results at different levels of caliper constraint. In the propensity matched comparison, there were no differences in overall survival, disease-specific survival, or local control between the SBRT and surgery groups, as shown in Figure 4, $A, B$, and $C$, for the most liberal caliper selection of 0.005 .

There were no treatment-related deaths associated with SBRT. Complications associated with SBRT included grade 1 to 2 pneumonitis in 41 patients $(51.9 \%)$ with only 1 $(1.3 \%)$ patient experiencing grade 3 pneumonitis. Other minor complications with SBRT included 4 rib fractures, 3 pleural effusions, lung collapse in 2, hemoptysis in 1 , and bacterial pneumonia in 1 . Among the 57 very high-risk surgical patients identified in Figure 4, $A$ to $C$, the operative mortality was $7.0 \%(4 / 57)$ with complications affecting $43.8 \%$ of this subgroup $(25 / 57)$. In this high-risk group, arrhythmias accounted for $21 \%$ of complications and pneumonia/respiratory failure accounted for $27 \%$ all of complications. Among the lower-risk surgical patients, the operative mortality was $2.7 \%(11 / 405)$ with complications occurring in $38.0 \%(154 / 405)$ of patients. In the low-risk group, arrhythmias accounted for $22.7 \%$ of all complications, whereas pneumonia/respiratory failure accounted for 
TABLE 1. Pretreatment and operative characteristics of surgically treated patients and patients undergoing SBRT for clinical stage I lung cancer

\begin{tabular}{|c|c|c|c|}
\hline Variable & $\begin{array}{c}\text { Surgery } \\
(n=462)\end{array}$ & $\begin{array}{c}\text { SBRT } \\
(n=76)\end{array}$ & $P$ value \\
\hline Age & $66.7 \pm 9.8(33-90)$ & $75 \pm 10(50-94)$ & $<.001$ \\
\hline$>75 y$ & $97(21 \%)$ & $39(51 \%)$ & $<.001$ \\
\hline Male gender & $34(43 \%)$ & $238(52 \%)$ & .19 \\
\hline T1 & $291(62.6 \%)$ & $57(75 \%)$ & .001 \\
\hline ACE score 2-3 & $171(37 \%)$ & $60(79 \%)$ & .001 \\
\hline $\mathrm{FEV}_{1} \%$ predicted & 0.785 & 0.42 & .001 \\
\hline DLCO $\%$ predicted & 0.9 & 0.66 & .001 \\
\hline \multicolumn{4}{|l|}{ Surgical procedure type } \\
\hline Wedge only & 49 & & \\
\hline Lobectomy & 322 & & \\
\hline Bilobectomy & 19 & & N/A \\
\hline Pneumonectomy & 22 & N/A & \\
\hline Wedge + lobectomy & 24 & & \\
\hline Segmentectomy & 16 & & \\
\hline Sleeve lobectomy & 10 & & \\
\hline \multicolumn{4}{|c|}{$\begin{array}{l}\text { For dichotomous variables, count numbers are listed; } P \text { values are calculated using } \chi^{2} \\
\text { statistics. For continuous variables, the median and range are listed, and } P \text { values are } \\
\text { calculated using the Mann-Whitney } U \text { test. } A C E \text {, Adult Co-Morbidity Evaluation; } \\
F E V_{l} \text {, forced expiratory volume in } 1 \text { second; } D L C O \text {, carbon monoxide diffusion in } \\
\text { the lung; } N / A \text {, not applicable. }\end{array}$} \\
\hline
\end{tabular}

$19.9 \%$, atelectasis $10.4 \%$, and prolonged air leaks ( $>7$ days) $11.4 \%$.

\section{DISCUSSION}

Surgical resection remains the gold standard for management of patients with early-stage lung cancer. However, we are often confronted with very high-risk patients secondary to severe pulmonary dysfunction or other comorbid conditions that make surgery prohibitive or, at the least, very hazardous. This study was designed to identify the highest-risk patients who underwent surgical resection and compare them with patients undergoing treatment with SBRT. It is important to note that the outcomes of patients analyzed in the propensity matched groups included only surgical patients with the greatest surgical risk owing to diminished pulmonary function and other comorbidities and that only intermediate-term results are currently available. Extrapolation of these results to healthier patients with a greater life expectancy owing to their overall medical condition should be done only with extreme caution. In the unmatched comparison, the local failure rate was higher in patients with stage IA disease in the SBRT-treated group than in the surgically treated group. Furthermore, surgical treatment altered the pathologic stage in $35 \%$ of patients, affecting both prognosis and potential adjuvant treatment. Although there was no difference in local failure rates and diseasespecific survival in patients with stage IB disease, it is difficult to make conclusions because of the very small number of patients in the SBRT group and the limited follow-up. Ex-
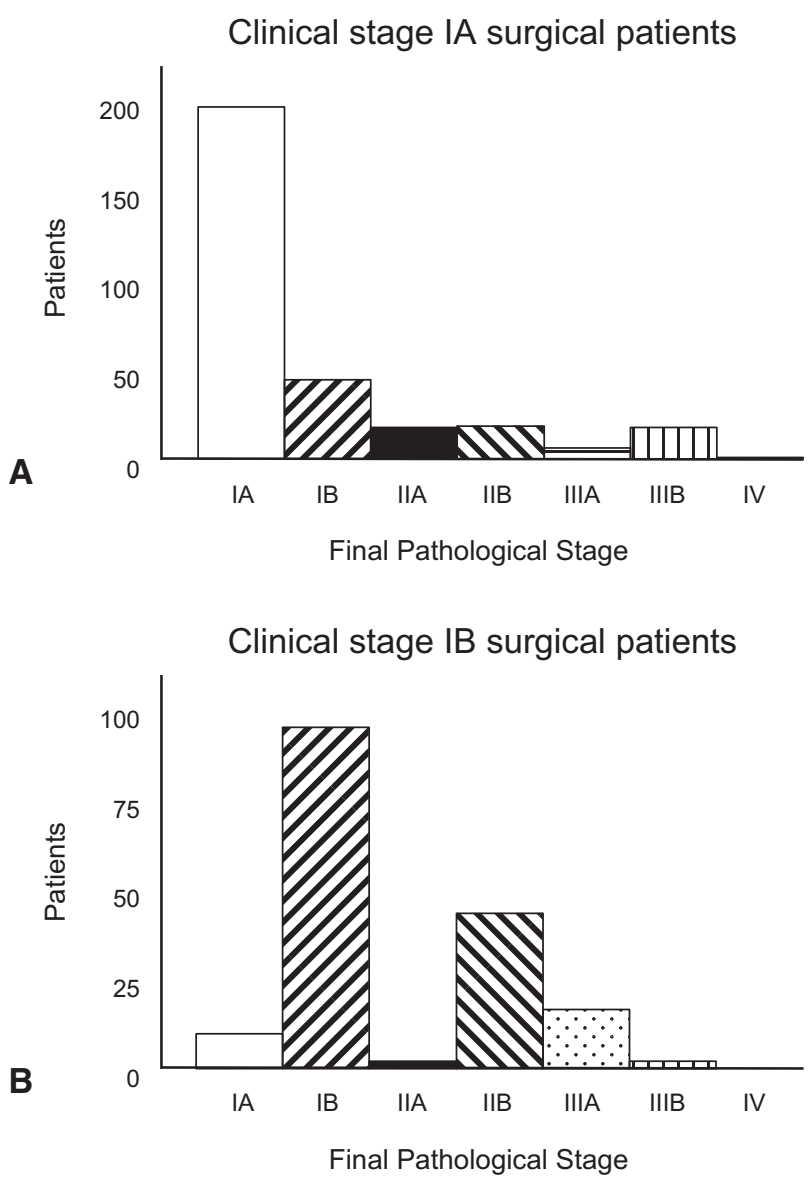

FIGURE 3. Pathologic stage of surgically treated patients among patients with clinical stage IA (A) and stage IB (B) disease.

trapolation of data from the high-risk patients regarding the efficacy of SBRT should not apply to patients with operable disease outside of an approved clinical trial.

This study does emphasize the acuity of the population being offered SBRT at our institution. There is a dramatic difference in pulmonary function, age, and comorbidity between the groups. Attempts to match patients on the basis of these parameters limited the number of surgical patients who could be compared with the SBRT patients. In reality, a large portion of the SBRT patients are simply patients who historically were not offered surgical treatment. Instead, these patients were likely treated with external beam radiation therapy or were not treated at all.

Historical data regarding nonsurgical therapy reveal that among untreated patients, lung cancer-specific 5-year survival has been reported as $23 \%$ for $\mathrm{T} 1$ lesions and $12 \%$ for T2 lesions with an overall 5-year survival of $9 \%$ and $5 \%$, respectively. ${ }^{2}$ Patients with stage I NSCLC treated with conventional external beam radiation therapy have overall and lung cancer-specific 5-year survivals of only $21 \% \pm 8 \%$ and $25 \% \pm 9 \%$, respectively, in a review of multiple trials. ${ }^{10}$ Radiofrequency ablation has been 
TABLE 2. Cox regression analysis of all surgically treated patients and all patients undergoing SBRT for stage I NSCLC*

\begin{tabular}{|c|c|c|c|c|}
\hline End point & Surgery events & SBRT events & Hazard ratio $(95 \%$ CI) & $P$ value \\
\hline Local tumor control & $22(4.8 \%)$ & $5(6.3 \%)$ & $0.47(0.16-1.41$ & .182 \\
\hline Cause-specific survival & $85(18.4 \%)$ & $12(15.2 \%)$ & $0.77(0.40-1.48)$ & .448 \\
\hline Overall survival & $172(37.2 \%)$ & $41(51.9 \%)$ & $0.66(0.43-0.92)$ & .020 \\
\hline
\end{tabular}

$\overline{S B R T}$, Stereotactic body radiation therapy; NSCLC, non-small cell lung cancer; $C I$, confidence interval. *Using Cox proportional hazard model adjusted for age, comorbidity score, and $\mathrm{T}$ stage.

proposed as an alternative nonsurgical option for patients with inoperable disease but has been associated with significant complications including pneumothoraces $(28 \%-55 \%)$ and hemoptysis. ${ }^{11-15}$ Furthermore, local progression after radiofrequency ablation has been as high as $42 \%$ at 27 months for stage I NSCLC. ${ }^{12}$

Sublobar resections have been investigated in patients with poor pulmonary function. The only prospective randomized study comparing complete lobectomies to sublobar resections failed to show any significant difference in long-

TABLE 3. Matched cohort by propensity score matching

\begin{tabular}{|c|c|c|c|}
\hline Variable & Surgery & SBRT & $P$ value \\
\hline \multicolumn{4}{|c|}{ A. Matching using caliper radii of $0.0005(n=23)$} \\
\hline Age (y) & $69(47-82)$ & $65(51-89)$ & .235 \\
\hline$<75 \mathrm{y}$ & 17 & 18 & \\
\hline$\geq 75 \mathrm{y}$ & 6 & 5 & \\
\hline Comorbidity score & $1(0-3)$ & $2(0-3)$ & .562 \\
\hline $0-1$ & 13 & 10 & \\
\hline $2-3$ & 10 & 13 & \\
\hline \multicolumn{4}{|l|}{ T stage } \\
\hline $\mathrm{T} 1$ & 16 & 14 & .536 \\
\hline $\mathrm{T} 2$ & 7 & 9 & \\
\hline Others & 0 & 0 & \\
\hline \multicolumn{4}{|c|}{ B. Matching using a caliper radius of $0.001(n=33)$} \\
\hline Age (y) & $69(47-82)$ & $68(51-89)$ & .376 \\
\hline$<75 \mathrm{y}$ & 25 & 25 & \\
\hline$\geq 75 y$ & 8 & 8 & \\
\hline Comorbidity score & $2(0-3)$ & $2(0-3)$ & .457 \\
\hline $0-1$ & 16 & 13 & \\
\hline $2-3$ & 17 & 20 & \\
\hline \multicolumn{4}{|l|}{ T stage } \\
\hline $\mathrm{T} 1$ & 22 & 21 & .796 \\
\hline $\mathrm{T} 2$ & 11 & 12 & \\
\hline Others & 0 & 0 & \\
\hline \multicolumn{4}{|c|}{ C. Matching using a caliper radius of $0.005(n=57)$} \\
\hline Age (y) & $73(47-90)$ & $71(50-94)$ & .843 \\
\hline$<75 \mathrm{y}$ & 37 & 34 & \\
\hline$\geq 75 y$ & 20 & 23 & \\
\hline Comorbidity score & $2(0-3)$ & $2(0-3)$ & .310 \\
\hline $0-1$ & 20 & 15 & \\
\hline $2-3$ & 37 & 42 & \\
\hline \multicolumn{4}{|l|}{$\mathrm{T}$ stage } \\
\hline T1 & 40 & 39 & .839 \\
\hline $\mathrm{T} 2$ & 17 & 18 & \\
\hline Others & 0 & 0 & \\
\hline
\end{tabular}

$S B R T$, Stereotactic body radiation therapy. Logistic regression approach was used to estimate probabilities of treatment assignment with age, comorbidity score, and $\mathrm{T}$ stage as covariates. term survival, but the local recurrence rate among patients in the limited resection group was 3 times higher $(6 \%$ vs $18 \%) .{ }^{16}$ More recently, segmentectomies have been shown to have equivocal local control and long-term survival in elderly patients with NSCLC tumors less than $3.5 \mathrm{~cm}$. Moreover, patients treated with sublobar resections in this study had fewer complications. ${ }^{17}$ Sublobar resections have also been offered to patients with compromised pulmonary function with or without brachytherapy in a randomized fashion. Among 147 sublobar resections in high-risk patients for stage I lung cancer, the local recurrence and regional recurrence rates were $7.2 \%$ and $6.8 \%$, respectively. ${ }^{18}$ For patients with stage 1B disease, the addition of brachytherapy to sublobar resection resulted in similar local recurrence rates and disease-free survival at 4 years compared with lobectomy. ${ }^{19}$ The mortality in the subgroup undergoing sublobar resection and brachytherapy was $2.4 \%$ with a complication rate of $46 \% .{ }^{19}$ By way of comparison, patients undergoing brachytherapy/wedge resection in this study had an average $\mathrm{FEV}_{1} \%$ of $52 \%$ to $53 \%$ compared with our SBRT group, with a mean $\mathrm{FEV}_{1} \%$ of $42 \% .{ }^{19,20}$ This emphasizes the fact that patients offered SBRT in our study are at very high risk even compared with patients currently being offered sublobar resection with or without brachytherapy.

Although there has been no direct comparison with surgery, there have been several studies examining SBRT in high-risk patients. Onishi and associates ${ }^{5}$ have reported the largest experience with the longest follow-up with a 5-year overall survival of $47 \%$, a local failure rate of $13.5 \%$, and a regional failure rate of $8.2 \%$. Others have reported local failure rates ranging from $3 \%$ to $16 \% .^{3,4,6-8,21}$ These studies have demonstrated a survival advantage in stage I lung cancer compared with no therapy or historical controls of conventional external beam radiation therapy. Our current results with SBRT are congruent with others examining SBRT treatment in high-risk patients.

SBRT has been performed in high-risk patients with very limited toxicity. Acute severe toxicity has been reported in $2 \%$ to $8 \%$ of treated patients and is manifest as severe pneumonitis, dermatitis, severe pain, or esophagitis. ${ }^{5-7}$ In this study, minor (grade 1-2) acute pneumonitis occurred in $52 \%$ undergoing SBRT and was generally self-limited, with grade 3 toxicity occurring in $1.3 \%$. There has been no severe late toxicity although our follow-up is short to date. Overall, in the surgical group the operative mortality 

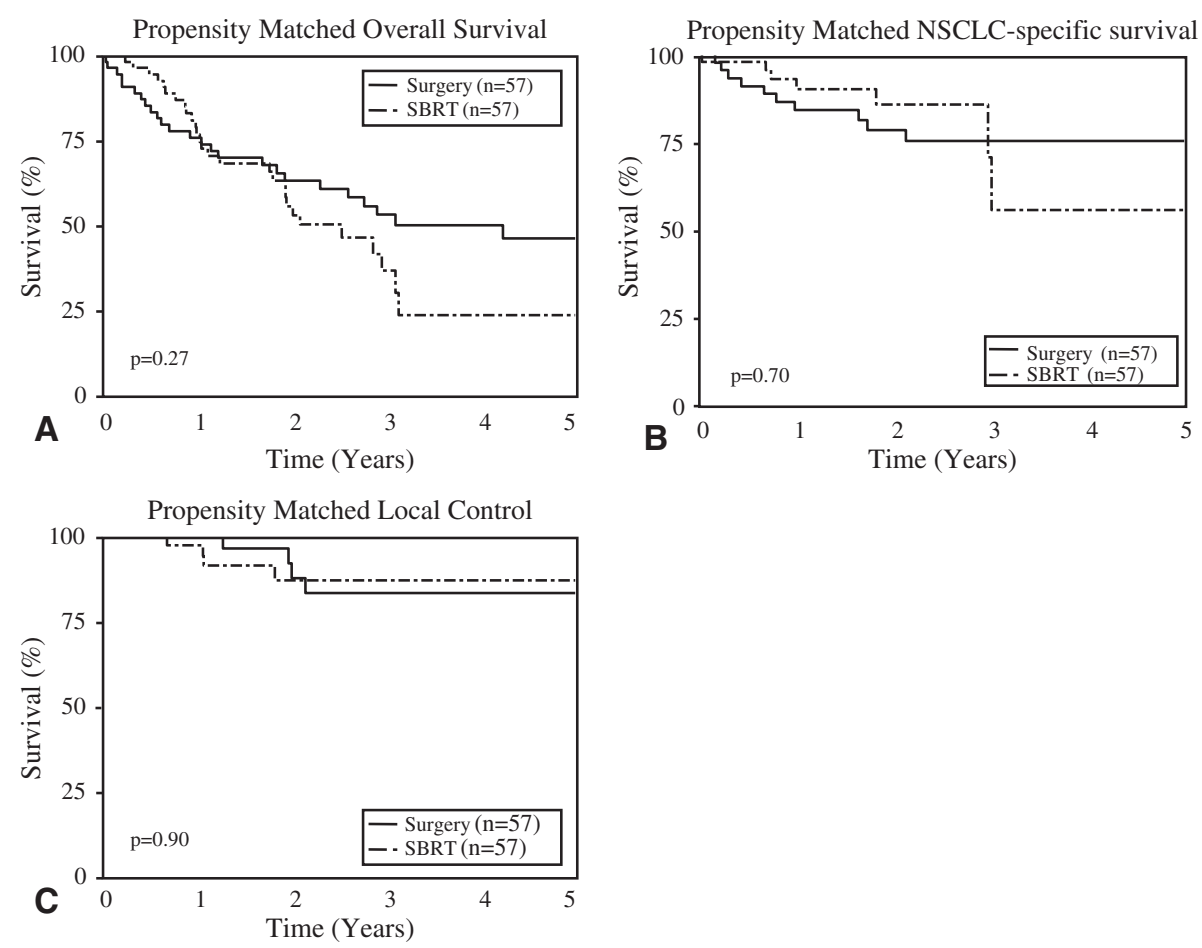

FIGURE 4. Overall survival (A), NSCLC-specific survival (B), and local tumor control (C) in a propensity matched comparison of surgically treated patients versus SBRT. SBRT, Stereotactic body radiation therapy; NSCLC, non-small cell lung cancer.

was $3.2 \%(15 / 462)$ whereas the operative mortality in the very high-risk surgical patients was $7.0 \%$ (4/57). This is comparable with other large surgical series of lobectomy among these groups of patients with lung cancer. ${ }^{22-24}$

Although this is the first report comparing an emerging technology such as SBRT with surgery, this study is limited by the relatively short follow-up period among patients receiving SBRT. There are few institutions in the United States that have a large cohort of patients with long-term follow-up to provide such a comparison. Although we have included all patients with clinical stage I lung cancer receiving SBRT, the short follow-up is a representative of our institution's 4-year experience with this technology in treating lung cancer. No SBRT patients in our series have been lost to follow-up. The relative lack of long-term follow-up reflects, in part, their underlying comorbidities, which limit their survival. In light of this, analysis of local tumor control and lung cancer-specific survival may skew the data in favor of SBRT. Owing to the medical comorbidities of the SBRT patients, those dying of non-cancer related deaths were counted as long-term lung cancer-specific survivors with local control of their disease. Longer follow-up is essential for adequate comparison of these groups and is ongoing.

Another limitation in our study, as in other studies of nonsurgical therapy, is a discrepancy in the definitions of local tumor control. Local control among patients treated surgi- cally was defined as the lack of tumor recurrence within the lung parenchyma or mediastinal lymph nodes. In contrast, local control among patients receiving SBRT was defined as the lack of tumor progression radiographically in the primary lobe. However, $3(3.9 \%)$ of 76 patients receiving SBRT in our study had a recurrence within mediastinal lymph nodes. Unlike these high-risk inoperable patients, tissue confirmation of disease recurrence will be requisite in clinical trials comparing SBRT with surgery in patients that are fit for surgery.

The lack of preoperative surgical staging in the SBRT patients is also an important limitation of this study. Treatment options were limited in these high-risk patients, and it was often determined that surgical staging would not significantly alter the treatment plan. Among operable and even marginal patients, surgical staging with endobronchial ultrasonography or mediastinoscopy is essential both for prognosis and for treatment planning.

Treatment of these very high-risk patients with early-stage lung cancer remains a challenge. Although some of these patients may undergo surgical treatment, many have comorbid conditions that preclude surgical intervention. SBRT offers a low-risk effective alternative to these patients with few other options for treatment. Anticipated randomized trials should help elucidate the relative role of SBRT in the treatment armamentarium of early-stage lung cancer. SBRT should not currently be recommended to patients with 
operable lung cancer until prospective clinical trials are completed to support this approach.

\section{References}

1. McGarry RC, Song G, des Rosieres P, Timmerman R. Observation-only management of early stage, medically inoperable lung cancer: poor outcome. Chest. 2002;121:1155-8.

2. Raz DJ, Zell JA, Ou SH, Gandara DR, Anton-Culver H, Jablons DM. Natural history of stage I non-small cell lung cancer: implications for early detection. Chest. 2007;132:193-9.

3. Baumann P, Nyman J, Hoyer M, Gagliardi G, Lax I, Wennberg B, et al. Stereotactic body radiotherapy for medically inoperable patients with stage I nonsmall cell lung cancer-a first report of toxicity related to COPD/CVD in a nonrandomized prospective phase II study. Radiother Oncol. 2008;88:359-67.

4. Lagerwaard FJ, Haasbeek CJ, Smit EF, Slotman BJ, Senan S. Outcomes of risk adapted fractionated stereotactic radiotherapy for stage I non-small-cell lung cancer. Int J Radiat Oncol Biol Phys. 2008;70:685-92.

5. Onishi H, Shirato H, Nagata Y, Hiraoka M, Fujino M, Gomi K, et al. Hypofractionated stereotactic radiotherapy (HypoFXSRT) for stage I non-small cell lung cancer: updated results of 257 patients in a Japanese multi-institutional study. J Thorac Oncol. 2007;2(7 Suppl. 3):S94-100.

6. Timmerman R, Papiez L, McGarry R, Likes L, DesRosiers C, Frost S, et al. Extracranial stereotactic radioablation: results of a phase I study in medically inoperable stage I non-small cell lung cancer. Chest. 2003;124:1946-55.

7. Onimaru R, Shirato H, Shimizu S, Kitamura K, Xu B, Fukumoto S, et al. Tolerance of organs at risk in small-volume, hypofractionated, image-guided radiotherapy for primary and metastatic lung cancers. Int J Radiat Oncol Biol Phys. 2003; 56:126-35.

8. Uematsu M, Shioda A, Suda A, Fukui T, Ozeki Y, Hama Y, et al. Computed tomography-guided frameless stereotactic radiotherapy for stage I non-small cell lung cancer: a 5-year experience. Int J Radiat Oncol Biol Phys. 2001;51: 666-70.

9. Goldstraw P, Crowley J, Chansky K, Giroux DJ, Groome PA, Rami-Porta R, et al. The IASLC Lung Cancer Staging Project: proposals for the revision of the TNM stage groupings in the forthcoming (seventh) edition of the TNM classification of malignant tumours. J Thorac Oncol. 2007;2:706-14.

10. Qiao X, Tullgren O, Lax I, Sirzen F, Lewensohn R. The role of radiotherapy in treatment of stage I non-small cell lung cancer. Lung Cancer. 2003;41:1-11.

11. Kang S, Luo R, Liao W, Wu H, Zhang X, Meng Y. Single group study to evaluate the feasibility and complications of radiofrequency ablation and usefulness of post treatment position emission tomography in lung tumours. World J Surg Oncol. 2004;2:30.

12. Pennathur A, Luketich JD, Abbas G, Chen M, Fernando HC, Gooding WE, et al. Radiofrequency ablation for the treatment of stage I non-small cell lung cancer in high-risk patients. J Thorac Cardiovasc Surg. 2007;134:857-64.

13. Sakurai J, Hiraki T, Mukai T, Mimura H, Yasui K, Gobara H, et al. Intractable pneumothorax due to bronchopleural fistula after radiofrequency ablation of lung tumors. J Vasc Interv Radiol. 2007;18:141-5.

14. Simon CJ, Dupuy DE. Current role of image-guided ablative therapies in lung cancer. Expert Rev Anticancer Ther. 2005;5:657-66.

15. Yamagami T, Kato T, Hirota T, Yoshimatsu R, Matsumoto T, Nishimura T. Pneumothorax as a complication of percutaneous radiofrequency ablation for lung neoplasms. $J$ Vasc Interv Radiol. 2006;17:1625-9.

16. Ginsberg RJ, Rubinstein LV. Randomized trial of lobectomy versus limited resection for T1 N0 non-small cell lung cancer. Lung Cancer Study Group. Ann Thorac Surg. 1995;60:615-22.

17. Kilic A, Schuchert MJ, Pettiford BL, Pennathur A, Landreneau JR, Landreneau JP, et al. Anatomic segmentectomy for stage I non-small cell lung cancer in the elderly. Ann Thorac Surg. 2009;87:1662-6.

18. El-Sherif A, Gooding WE, Santos R, Pettiford B, Ferson PF, Fernando HC, et al. Outcomes of sublobar resection versus lobectomy for stage I non-small cell lung cancer: a 13-year analysis. Ann Thorac Surg. 2006;82:408-15.

19. Birdas TJ, Koehler RP, Colonias A, Trombetta M, Maley RH Jr, Landreneau RJ, et al. Sublobar resection with brachytherapy versus lobectomy for stage Ib nonsmall cell lung cancer. Ann Thorac Surg. 2006;81:434-8.

20. Santos R, Colonias A, Parda D, Trombetta M, Maley RH, Macherey R, et al. Comparison between sublobar resection and ${ }^{125}$ Iodine brachytherapy after sublobar resection in high-risk patients with Stage I non-small-cell lung cancer. Surgery. 2003;134:691-7.

21. Hof H, Muenter M, Oetzel D, Hoess A, Debus J, Herfarth K. Stereotactic singledose radiotherapy (radiosurgery) of early stage nonsmall-cell lung cancer (NSCLC). Cancer. 2007;110:148-55.

22. Allen MS, Darling GE, Pechet TT, Mitchell JD, Herndon JE, Landreneau RJ, et al. Morbidity and mortality of major pulmonary resections in patients with earlystage lung cancer: initial results of the randomized, prospective ACOSOG Z0030 trial. Ann Thorac Surg. 2006;81:1013-9.

23. Harpole DH Jr, DeCamp MM Jr, Daley J, Hur K, Oprian CA, Henderson WG, et al. Prognostic models of thirty-day mortality and morbidity after major pulmonary resection. J Thorac Cardiovasc Surg. 1999;117:969-79.

24. Strand TE, Rostad H, Damhuis RA, Norstein J. Risk factors for 30-day mortality after resection of lung cancer and prediction of their magnitude. Thorax. 2007;62: 991-7. 
APPENDIX A. Adult Comorbidity Evaluation-27.

\begin{tabular}{|c|c|c|c|}
\hline \multirow{6}{*}{$\begin{array}{l}\text { Date } \\
\text { Coder's Initials } \\
\text { Oncology Center } \\
\text { Accession \# } \\
\text { Sequence \# }\end{array}$} & \multirow{2}{*}{\multicolumn{3}{|c|}{ F YOU HAVE QUESTIONS, PLEASE CALL 314-362-7508 AND ASK FC }} \\
\hline & & & \\
\hline & \multirow{2}{*}{\multicolumn{3}{|c|}{ Adult Comorbidity Evaluation-27 }} \\
\hline & 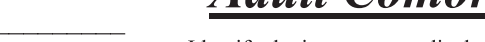 & & \\
\hline & \multirow{2}{*}{\multicolumn{3}{|c|}{$\begin{array}{l}\text { Identify the important medical comorbidities and grade severity using the index. } \\
\text { Overall Comorbidity Score is defined according to the highest ranked single ailment, } \\
\text { except in the case where two or more Grade } 2 \text { ailments occur in different organ systems. } \\
\text { In this situation. the overall comorbiditv score should be designated Grade } 3 \text {. }\end{array}$}} \\
\hline & & & \\
\hline $\begin{array}{c}\text { Cogent comorbid } \\
\text { ailment }\end{array}$ & $\begin{array}{c}\text { Grade } 3 \\
\text { Severe Decompensation }\end{array}$ & $\begin{array}{c}\text { Grade } 2 \\
\text { Moderate Decompensation }\end{array}$ & $\begin{array}{c}\text { Grade } 1 \\
\text { Mild Decompensation }\end{array}$ \\
\hline \multicolumn{4}{|c|}{ Cardiovascular System } \\
\hline Myocardial Infarct & $\square \mathrm{MI} \leq 6$ months & $\square \mathrm{MI}>6$ months ago & $\square$ MI by ECG only, age undetermined \\
\hline $\begin{array}{l}\text { Angina / Coronary } \\
\text { Artery Disease }\end{array}$ & $\square$ Unstable angina & $\begin{array}{l}\square \text { Chronic exertional angina } \\
\square \text { Recent ( } \leq 6 \text { months) Coronary Artery } \\
\text { Bypass Graft }(\mathrm{CABG}) \text { or Percutaneous } \\
\text { Transluminal Coronary Angioplasty } \\
\text { (PTCA) } \\
\square \text { Recent ( } \leq 6 \text { months) coronary stent }\end{array}$ & $\begin{array}{l}\square \text { ECG or stress test evidence or } \\
\text { catheterization evidence of coronary } \\
\text { disease without symptoms } \\
\square \text { Angina pectoris not requiring } \\
\text { hospitalization } \\
\square \text { CABG or PTCA ( }>6 \text { mos.) } \\
\square \text { Coronary stent }(>6 \text { mos.) }\end{array}$ \\
\hline $\begin{array}{l}\text { Congestive Heart } \\
\text { Failure (CHF) }\end{array}$ & $\begin{array}{l}\square \text { Hospitalized for CHF within past } 6 \\
\text { months } \\
\square \text { Ejection fraction }<20 \%\end{array}$ & $\begin{array}{l}\text { Hospitalized for } \mathrm{CHF}>6 \text { months prior } \\
\square \text { CHF with dyspnea which limits } \\
\text { activities }\end{array}$ & $\begin{array}{l}\text { CHF with dyspnea which has } \\
\text { responded to treatment } \\
\square \text { Exertional dyspnea } \\
\square \text { Paroxysmal Nocturnal Dyspnea (PND) }\end{array}$ \\
\hline Arrhythmias & $\square$ Ventricular arrhythmia $\leq 6$ months & $\begin{array}{l}\square \text { Ventricular arrhythmia }>6 \text { months } \\
\square \text { Chronic atrial fibrillation or flutter } \\
\square \text { Pacemaker }\end{array}$ & $\begin{array}{l}\square \text { Sick Sinus Syndrome } \\
\square \text { Supraventricular tachycardia }\end{array}$ \\
\hline Hypertension & $\begin{array}{l}\square \mathrm{DBP} \geq 130 \mathrm{~mm} \mathrm{Hg} \\
\square \text { Severe malignant papilledema or other } \\
\text { eye changes } \\
\square \text { Encephalopathy }\end{array}$ & $\begin{array}{l}\square \text { DBP } 115-129 \mathrm{~mm} \mathrm{Hg} \\
\square \text { DBP 90-114 mm Hg while taking } \\
\text { antihypertensive medications } \\
\square \text { Secondary cardiovascular symptoms: } \\
\text { vertigo, epistaxis, headaches }\end{array}$ & \begin{tabular}{|l|}
$\square$ DBP $90-114 \mathrm{~mm} \mathrm{Hg}$ while not taking \\
antihypertensive medications \\
$\square$ DBP $<90 \mathrm{~mm} \mathrm{Hg}$ while taking \\
antihypertensive medications \\
$\square$ Hypertension, not otherwise specified
\end{tabular} \\
\hline Venous Disease & $\begin{array}{l}\square \text { Recent PE }(\leq 6 \text { mos.) } \\
\square \text { Use of venous filter for PE's }\end{array}$ & $\begin{array}{l}\square \text { DVT controlled with Coumadin or } \\
\text { heparin } \\
\square \text { Old PE }>6 \text { months }\end{array}$ & $\begin{array}{l}\square \text { Old DVT no longer treated with } \\
\text { Coumadin or Heparin }\end{array}$ \\
\hline $\begin{array}{l}\text { Peripheral Arterial } \\
\text { Disease }\end{array}$ & $\begin{array}{l}\square \text { Bypass or amputation for gangrene or } \\
\text { arterial insufficiency }<6 \text { months ago } \\
\square \text { Untreated thoracic or abdominal } \\
\text { aneurysm }(\geq 6 \mathrm{~cm})\end{array}$ & $\begin{array}{l}\square \text { Bypass or amputation for gangrene or } \\
\text { arterial insufficiency }>6 \text { months ago } \\
\square \text { Chronic insufficiency }\end{array}$ & $\begin{array}{l}\square \text { Intermittent claudication } \\
\square \text { Untreated thoracic or abdominal } \\
\text { aneurysm }(<6 \mathrm{~cm}) \\
\square \text { s/p abdominal or thoracic aortic } \\
\text { aneurysm repair }\end{array}$ \\
\hline \multicolumn{4}{|l|}{ Respiratory System } \\
\hline & 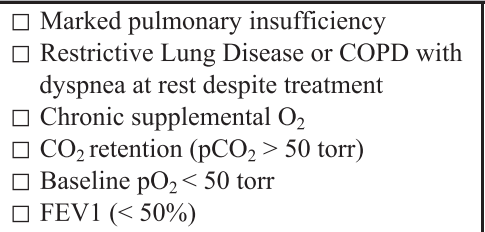 & $\begin{array}{l}\square \text { Restrictive Lung Disease or COPD } \\
\text { (chronic bronchitis, emphysema, or } \\
\text { asthma) with dyspnea which limits } \\
\text { activities } \\
\square \text { FEV1 }(51 \%-65 \%)\end{array}$ & $\begin{array}{l}\square \text { Restrictive Lung Disease or COPD } \\
\text { (chronic bronchitis, emphysema, or } \\
\text { asthma) with dyspnea which has } \\
\text { responded to treatment } \\
\square \text { FEV1 }(66 \%-80 \%)\end{array}$ \\
\hline \multicolumn{4}{|c|}{ Gastrointestinal System } \\
\hline Hepatic & $\begin{array}{l}\square \text { Portal hypertension and/or esophageal } \\
\text { bleeding } \leq 6 \text { mos. (Encephalopathy, } \\
\text { Ascites, Jaundice with Total } \\
\text { Bilirubin }>2 \text { ) }\end{array}$ & $\begin{array}{l}\square \text { Chronic hepatitis, cirrhosis, portal } \\
\text { hypertension with moderate } \\
\text { symptoms "compensated hepatic } \\
\text { failure" }\end{array}$ & $\begin{array}{l}\square \text { Chronic hepatitis or cirrhosis without } \\
\text { portal hypertension } \\
\square \text { Acute hepatitis without cirrhosis } \\
\square \text { Chronic liver disease manifested on } \\
\text { biopsy or persistently elevated } \\
\text { bilirubin }(>3 \mathrm{mg} / \mathrm{dl})\end{array}$ \\
\hline Stomach / Intestine & $\begin{array}{l}\square \text { Recent ulcers ( } \leq 6 \text { months ago) requiring } \\
\text { blood transfusion }\end{array}$ & $\begin{array}{l}\square \text { Ulcers requiring surgery or } \\
\text { transfusion }>6 \text { months ago }\end{array}$ & $\begin{array}{l}\square \text { Diagnosis of ulcers treated with meds } \\
\square \text { Chronic malabsorption syndrome } \\
\square \text { Inflammatory bowel disease (IBD) on } \\
\text { meds or h/o with complications and/or } \\
\text { surgery }\end{array}$ \\
\hline Pancreas & $\begin{array}{l}\text { Acute or chronic pancreatitis with major } \\
\text { complications (phlegmon, abscess, or } \\
\text { pseudocyst) }\end{array}$ & $\begin{array}{l}\square \text { Uncomplicated acute pancreatitis } \\
\square \text { Chronic pancreatitis with minor } \\
\text { complications (malabsorption, } \\
\text { impaired glucose tolerance, or GI } \\
\text { bleeding) }\end{array}$ & $\begin{array}{l}\square \text { Chronic pancreatitis w/o } \\
\text { complications }\end{array}$ \\
\hline
\end{tabular}




\begin{tabular}{|c|c|c|c|}
\hline $\begin{array}{l}\text { Cogent comorbid } \\
\text { ailment }\end{array}$ & $\begin{array}{c}\text { Grade 3 } \\
\text { Severe Decompensation }\end{array}$ & $\begin{array}{c}\text { Grade 2 } \\
\text { Moderate Decompensation }\end{array}$ & $\begin{array}{c}\text { Grade 1 } \\
\text { Mild Decompensation }\end{array}$ \\
\hline \multicolumn{4}{|l|}{ Renal System } \\
\hline End-stage renal disease & $\begin{array}{l}\square \text { Creatinine }>3 \mathrm{mg} \% \text { with multi-organ } \\
\text { failure, shock, or sepsis } \\
\square \text { Acute dialysis }\end{array}$ & $\begin{array}{l}\square \text { Chronic Renal Insufficiency with } \\
\text { creatinine }>3 \mathrm{mg} \% \\
\square \text { Chronic dialysis }\end{array}$ & $\begin{array}{l}\square \text { Chronic Renal Insufficiency with } \\
\text { creatinine } 2-3 \mathrm{mg} \% \text {. }\end{array}$ \\
\hline \multicolumn{4}{|c|}{ Endocrine System (Code the comorbid ailments with the $(*)$ in both the Endocrine system and other organ systems if applicable) } \\
\hline Diabetes Mellitus & $\begin{array}{l}\square \text { Hospitalization } \leq 6 \text { months for DKA } \\
\square \text { Diabetes causing end-organ failure } \\
\square \text { retinopathy } \\
\square \text { neuropathy } \\
\square \text { nephropathy* } \\
\square \text { coronary disease* } \\
\square \text { peripheral arterial disease* }\end{array}$ & $\begin{array}{l}\square \text { IDDM without complications } \\
\square \text { Poorly controlled AODM with } \\
\text { oral agents }\end{array}$ & $\square$ AODM controlled by oral agents only \\
\hline \multicolumn{4}{|l|}{ Neurological System } \\
\hline Stroke & $\begin{array}{l}\square \text { Acute stroke with significant neurologic } \\
\text { deficit }\end{array}$ & $\square$ Old stroke with neurologic residual & $\begin{array}{l}\square \text { Stroke with no residual } \\
\square \text { Past or recent TIA }\end{array}$ \\
\hline Dementia & $\begin{array}{l}\square \text { Severe dementia requiring full support for } \\
\text { activities of daily living }\end{array}$ & $\begin{array}{l}\text { Moderate dementia (not completely } \\
\text { self-sufficient, needs supervising) }\end{array}$ & $\square$ Mild dementia (can take care of self) \\
\hline Paralysis & $\begin{array}{l}\square \text { Paraplegia or hemiplegia requiring full } \\
\text { support for activities of daily living }\end{array}$ & $\begin{array}{l}\text { Paraplegia or hemiplegia requiring } \\
\text { wheelchair, able to do some self care }\end{array}$ & $\begin{array}{l}\square \text { Paraplegia or hemiplegia, ambulatory } \\
\text { and providing most of self care }\end{array}$ \\
\hline Neuromuscular & $\begin{array}{l}\square \text { MS, Parkinson's, Myasthenia Gravis, or } \\
\text { other chronic neuromuscular disorder and } \\
\text { requiring full support for activities of daily } \\
\text { living }\end{array}$ & $\begin{array}{l}\text { MS, Parkinson's, Myasthenia } \\
\text { Gravis, or other chronic } \\
\text { neuromuscular disorder, but able to } \\
\text { do some self care }\end{array}$ & $\begin{array}{l}\text { MS, Parkinson's, Myasthenia Gravis, } \\
\text { or other chronic neuromuscular } \\
\text { disorder, but ambulatory and } \\
\text { providing most of self care }\end{array}$ \\
\hline \multicolumn{4}{|l|}{ Psychiatric } \\
\hline & $\begin{array}{l}\square \text { Recent suicidal attempt } \\
\square \text { Active schizophrenia }\end{array}$ & $\begin{array}{l}\square \text { Depression or bipolar disorder } \\
\text { uncontrolled } \\
\square \text { Schizophrenia controlled w/ meds }\end{array}$ & $\begin{array}{l}\square \text { Depression or bipolar disorder } \\
\text { controlled } \mathrm{w} / \text { medication }\end{array}$ \\
\hline \multirow[t]{2}{*}{ Rheumatologic } & \multicolumn{3}{|c|}{ (Incl. Rheumatoid Arthritis, Systemic Lupus, Mixed Connective Tissue Disorder, Polymyositis, Rheumatic Polymyositis) } \\
\hline & $\begin{array}{l}\square \text { Connective Tissue Disorder with } \\
\text { secondary end-organ failure (renal, } \\
\text { cardiac, CNS) }\end{array}$ & $\begin{array}{l}\square \text { Connective Tissue Disorder on } \\
\text { steroids or immunosuppressant } \\
\text { medications }\end{array}$ & $\begin{array}{l}\square \text { Connective Tissue Disorder on } \\
\text { NSAIDS or no treatment }\end{array}$ \\
\hline \multicolumn{4}{|c|}{ Immunological System (AIDS should not be considered a comorbidity for Kaposi's Sarcoma or Non-Hodgkin's Lymphoma) } \\
\hline AIDS & $\begin{array}{l}\text { Fulminant AIDS w/KS, MAI, PCP (AIDS } \\
\text { defining illness) }\end{array}$ & $\begin{array}{l}\square \mathrm{HIV}+\text { with } \mathrm{h} / \mathrm{o} \text { defining illness. } \\
\mathrm{CD} 4^{+}<200 / \mu \mathrm{L}\end{array}$ & $\begin{array}{l}\square \text { Asymptomatic HIV }+ \text { patient. } \\
\square \text { HIV }^{+} \text {w/o h/o AIDS defining illness. } \\
\mathrm{CD}^{+}>200 / \mu \mathrm{L}\end{array}$ \\
\hline \multicolumn{4}{|c|}{$\begin{array}{ll}\text { Malignancy } & \text { (Excluding Cutaneous Basal Cell Ca., Cutaneous SCCA, Carcinoma in-situ, and Intraepithelial Neoplasm) } \\
\end{array}$} \\
\hline $\begin{array}{l}\begin{array}{l}\text { Solid Tumor including } \\
\text { melanoma }\end{array} \\
\end{array}$ & $\begin{array}{l}\square \text { Uncontrolled cancer } \\
\square \text { Newly diagnosed but not yet treated } \\
\square \text { Metastatic solid tumor }\end{array}$ & $\begin{array}{l}\text { Any controlled solid tumor without } \\
\text { documented metastases, but } \\
\text { initially diagnosed and treated } \\
\text { within the last } 5 \text { years }\end{array}$ & $\begin{array}{l}\text { Any controlled solid tumor without } \\
\text { documented metastases, but initially } \\
\text { diagnosed and treated }>5 \text { years ago }\end{array}$ \\
\hline $\begin{array}{l}\text { Leukemia and } \\
\text { Myeloma }\end{array}$ & $\begin{array}{l}\square \text { Relapse } \\
\square \text { Disease out of control }\end{array}$ & $\begin{array}{l}\square 1^{\text {st }} \text { remission or new dx }<1 \mathrm{yr} \\
\square \text { Chronic suppressive therapy }\end{array}$ & $\begin{array}{l}\square \mathrm{H} / \mathrm{o} \text { leukemia or myeloma with last } \\
\mathrm{Rx}>1 \mathrm{yr} \text { prior }\end{array}$ \\
\hline Lymphoma & $\square$ Relapse & $\begin{array}{l}\square 1^{\text {st }} \text { remission or new dx }<1 \mathrm{yr} \\
\square \text { Chronic suppressive therapy }\end{array}$ & $\square \mathrm{H} / \mathrm{o}$ lymphoma $\mathrm{w} /$ last $\mathrm{Rx}>1 \mathrm{yr}$ prior \\
\hline \multicolumn{4}{|c|}{$\begin{array}{ll}\text { Substance Abuse } & \text { (Must be accompanied by social, behavioral, or medical complications) } \\
\end{array}$} \\
\hline Alcohol & $\square$ Delirium tremens & $\begin{array}{l}\square \text { Active alcohol abuse with social, } \\
\text { behavioral, or medical } \\
\text { complications }\end{array}$ & $\begin{array}{l}\square \mathrm{H} / \mathrm{o} \text { alcohol abuse but not presently } \\
\text { drinking }\end{array}$ \\
\hline Illicit Drugs & $\square$ Acute Withdrawal Syndrome & $\begin{array}{l}\square \text { Active substance abuse with social, } \\
\text { behavioral, or medical } \\
\text { complications }\end{array}$ & $\begin{array}{l}\square \text { H/o substance abuse but not presently } \\
\text { using }\end{array}$ \\
\hline \multicolumn{4}{|l|}{ Body Weight } \\
\hline Obesity & & $\square$ Morbid (i.e., BMI $\geq 38$ ) & \\
\hline
\end{tabular}

